\title{
The Somatic Chromosomes of Sophora fernandeziana (Fabaceae), an Endemic Tree from Robinson Crusoe Island ${ }^{1}$
}

\author{
Laura B. Stiefkens, ${ }^{2}$ Gabriel Bernardello, ${ }^{2}$ and Gregory 7. Anderson ${ }^{3}$
}

\begin{abstract}
The mitotic chromosome number and karyotype of Sophora fernandeziana (Phil.) Skottsb. (subfamily Papilionoideae) are reported for the first time. The chromosome number, $2 n=18$, is the modal number reported for the genus. The chromosomes are small (average length $1.55 \pm 0.23 \mu \mathrm{m}$ ) and bear no satellites. The intrachromosomal and interchromosomal asymmetry indices were $A_{1}=0.26$ and $A_{2}=0.18$, respectively. This symmetrical karyotype is composed of 7 metacentric +2 submetacentric pairs. This species is related to $S$. tetraptera J. Mill. from New Zealand. Both share the same chromosome number; unfortunately comparative karyotype data are not available for $S$. tetraptera. Our data suggest that no changes in chromosome number have occurred during the speciation of $S$. fernandeziana, in accordance with previous studies of other endemic species in the Juan Fernández flora and for island endemics in general. However, only a small percentage of actual karyotypes of island endemics have been studied, so generalizations about chromosomal evolution for such species are not yet well founded.
\end{abstract}

Robinson Crusoe Island (Masatierra) is one of the three islands of the small Juan Fernández Archipelago in Chile. It is located in the Pacific Ocean, $667 \mathrm{~km} \mathrm{~W}$ of continental Chile at $33^{\circ} \mathrm{S}$ latitude, having an estimated age of ca. 4 million yr old (Stuessy et al. 1984). The archipelago is well known for the high level of endemism among vascular plants (ca. $63 \%$ of the flora [Marticorena et al. 1998]). Unfortunately, currently more than $62 \%$ of the flora is considered rare, and two species are already extinct (Stuessy et al. 1998). The flora is threatened by both

\footnotetext{
${ }^{1}$ Support was provided from the National Science Foundation (U.S.A.), Consejo Nacional de Investigaciones Científicas y Ténicas (CONICET), and Consejo de Investigaciones Científicas y Tecnológicas de la provincia de Córdoba (CONICOR) (Argentina). Manuscript accepted 31 March 2000.

${ }^{2}$ Instituto Multidisciplinario de Biología Vegetal, C. C. 495, 5000 Córdoba, Argentina.

${ }^{3}$ The University of Connecticut, Department of Ecology and Evolutionary Biology, Storrs, Connecticut 06269-3043.
}

Pacific Science (2001), vol. 55, no. 1:71-75

(C) 2001 by University of Hawai'i Press

All rights reserved anthropogenic and natural phenomena, including fire, erosion, vegetation cutting, and continued introduction of animals and invasive plants (Stuessy et al. 1998).

There are the only two endemic legume species that inhabit the archipelago. Both are trees in the genus Sopbora L. and each of the main islands supports one species: $S$. masafuerana (Phil.) Skottsb. on Alexander Selkirk Island and S. fernandeziana (Phil.) Skottsb. on Robinson Crusoe Island. Sophora includes ca. 43 species (Polhill 1981, Sousa S. and Rudd 1993) partitioned among three sections. Sophora fernandeziana belongs to Sophora sect. Edwardsia (Salisb.) Taub., characterized by having a calyx without an upper lip, stamens and style exserted, lower petals all basically similar, standard not strongly reflexed, and pods often four-winged. This section comprises about 10 species: one each on Réunion Island and Hawai $i$, and the remainder on Lord Howe Island, New Zealand, and southwestern South America (Polhill 1981).

Chromosomal surveys based on haploid chromosome numbers (Sanders et al. 1983, Spooner et al. 1987, Sun et al. 1990) have been made for 38 of the 156 native and endemic species of the Juan Fernández Archipelago (Marticorena et al. 1998). However, 
none of these has included Sophora, and there are no published karyotype analyses. Worldwide, chromosomes have been counted for only 26 species of Sophora, with several chromosome numbers reported (cf. Federov 1974, Goldblatt 1981a,b,c, 1984, 1988, 1990, 1991, 1994, 1996, 1998). In this paper, we provide data on the somatic chromosome number and the karyotype of $S$. fernandeziana. These data are basic to determine the importance of chromosomal changes during evolution of species on this archipelago.

\section{MATERIALS AND METHODS}

The studied material was collected in Chile, Juan Fernández Archipelago, Robinson Crusoe Island, Corporación Nacional Forestal gardens, 27 January 1996 (G. F. Anderson 3064). A voucher specimen is deposited in Torrey Herbarium, University of Connecticut (CONN).

Mitotic chromosomes in somatic cells of root tips were analyzed from squashes of primary roots growing from germinating seeds. Seeds were soaked in tap water for $24 \mathrm{hr}$. They were then put in petri dishes lined with filter paper moistened with gibberellic acid (GA3, $1000 \mathrm{ppm}$ ) and were regularly watered with the same solution. Petri dishes were kept in the dark in a warming oven at $30^{\circ} \mathrm{C}$. Root tips were cut when the primary roots were 2$10 \mathrm{~mm}$ long and were pretreated at room temperature for $2 \mathrm{hr}$ in a saturated solution of p-dichlorobenzene in water. Root tips were rinsed in distilled water and fixed in freshly made ethanol:glacial acetic acid $(3: 1)$ at room temperature for $24 \mathrm{hr}$. After fixation, they were hydrolyzed with $5 \mathrm{~N} \mathrm{HCl}$ for $40 \mathrm{~min}$ at room temperature and put in Feulgen solution (basic fuchsin) for $2 \mathrm{hr}$ at room temperature in the dark. Root-tip meristem cells were isolated on a slide and squashed. Slides were made permanent in Euparal after removing the cover slips by freezing with liquid carbon dioxide.

Cells selected for measurements were photographed with phase-contrast optics and Kodak T-Max film. Ten cells from five individuals (two from each) were photographed and the photographs were used to determine the length of the following for each chromosome pair: s (short arm), l (long arm), and c (total chromosome length). The centromeric index $(i=100 \mathrm{~s} / \mathrm{c})$ and the arm ratio $(\mathrm{r}=1 / \mathrm{s})$ were then calculated and used to classify the chromosomes according to Levan et al. (1964) and to determine homologous chromosomes. Karyograms were constructed by organizing the chromosomes into groups according to their arm ratio (from metacentric to submetacentric), ordering them by decreasing length within each category. The resulting idiogram was based on the mean values obtained. Karyotype asymmetry was estimated using the indices of Romero Zarco (1986) and Stebbins' classification (1971).

\section{RESULTS}

The examination of 30 cells, from five individuals, showed that the somatic chromosome number of $S$. fernandeziana is $2 n=18$ (Figure 1). The chromosomes are small (Table 1), ranging from 1.0 to $2.3 \mu \mathrm{m}$, with an average mean chromosome length of $1.55 \pm 0.23$. No satellites were observed. The total haploid chromosome length of the karyotype based on the mean chromosome length was $14 \mu \mathrm{m}$. The karyotype is symmetrical with $7 \mathrm{~m}$ (metacentric) $+2 \mathrm{sm}$ (submetacentric) chromosome pairs (Figure 2). The intrachromosomal and interchromosomal asymmetry indices were $A_{1}=0.26$ and $\mathrm{A}_{2}=0.18$, respectively. According to Steb-

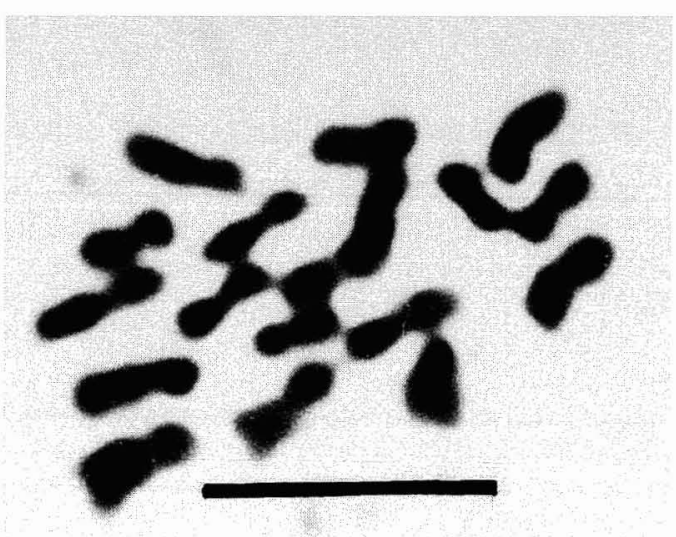

FIGURE 1. Photomicrograph of mitotic metaphase of Sophora fernandeziana, $2 n=18$. Scale bar $=5 \mu \mathrm{m}$. 
TABLE 1

Measurements in $\mu \mathrm{m}$ (Mean $\pm \mathrm{SD}$ ) and Chromosomic Indices of Somatic Chromosomes of Sophora fernandeziana

\begin{tabular}{lcccccc}
\hline \hline Pair & $\mathrm{s}$ & $\mathrm{l}$ & $\mathrm{c}$ & $\mathrm{r}$ & $\mathrm{i}$ & Chromosome Type \\
\hline 1 & $0.88 \pm 0.11$ & $1.09 \pm 0.18$ & $1.96 \pm 0.24$ & 1.24 & 44.58 & $\mathrm{~m}$ \\
2 & $0.78 \pm 0.12$ & $0.98 \pm 0.11$ & $1.75 \pm 0.22$ & 1.26 & 44.28 & $\mathrm{~m}$ \\
3 & $0.71 \pm 0.11$ & $0.94 \pm 0.14$ & $1.65 \pm 0.23$ & 1.33 & 42.88 & $\mathrm{~m}$ \\
4 & $0.71 \pm 0.14$ & $0.84 \pm 0.15$ & $1.55 \pm 0.25$ & 1.17 & 46.07 & $\mathrm{~m}$ \\
5 & $0.65 \pm 0.10$ & $0.80 \pm 0.13$ & $1.45 \pm 0.22$ & 1.22 & 44.94 & $\mathrm{~m}$ \\
6 & $0.63 \pm 0.10$ & $0.75 \pm 0.10$ & $1.37 \pm 0.16$ & 1.19 & 45.55 & $\mathrm{~m}$ \\
7 & $0.54 \pm 0.15$ & $0.65 \pm 0.09$ & $1.19 \pm 0.15$ & 1.20 & 45.54 & $\mathrm{~m}$ \\
8 & $0.57 \pm 0.10$ & $1.16 \pm 0.15$ & $1.73 \pm 0.24$ & 2.04 & 32.85 & $\mathrm{sm}$ \\
9 & $0.43 \pm 0.10$ & $0.93 \pm 0.25$ & $1.36 \pm 0.26$ & 2.16 & 31.65 & $\mathrm{sm}$ \\
\hline
\end{tabular}

Note: Abbreviations after Levan et al. (1964): s, short arm; l, long arm; c, total chromosome length; r, arm ratio; i, centromeric index; $m$, metacentric; sm, submetacentric.

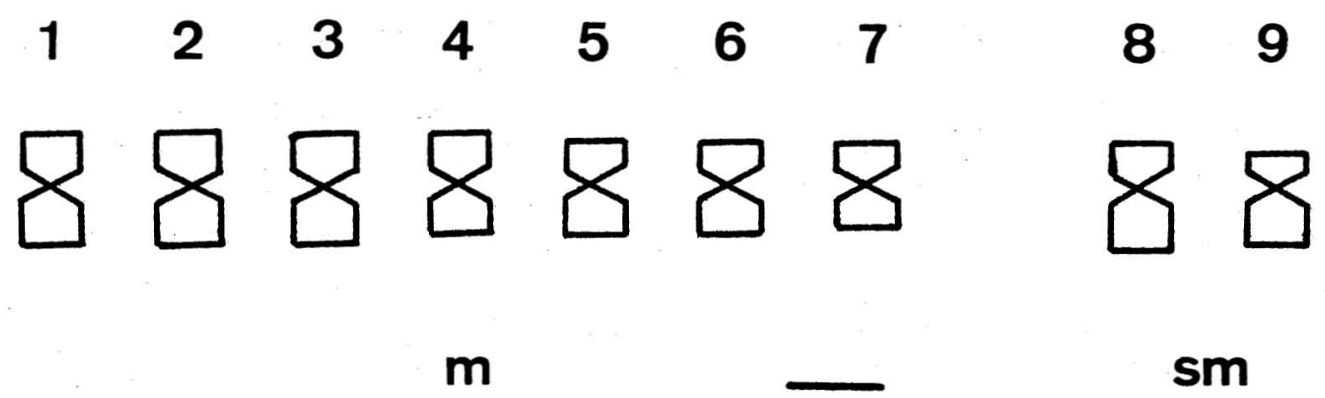

FIGURE 2. Idiogram of Sophora fernandeziana based on mean chromosome values (see Table 1). Scale bar $=$ $2 \mu \mathrm{m}$.

bins' (1971) classification, the karyotype falls in the " $2 \mathrm{~A}$ " category.

\section{DISCUSSION}

The diploid chromosome number of $S$. fernandeziana, at $2 n=18$, is the modal number for Sophora. Several chromosome numbers have been reported for this genus: $n=9,18$, 11 , and $2 n=18,28,36,16,32,22,54$, in decreasing order of frequency in each case (cf. Federov 1974, Goldblatt 1981a,b,c, 1984, 1988, 1990, 1991, 1994, 1996, 1998). The tribe Sophoreae probably had a polyploid origin with the basic number $x=14$, from whence a decreasing aneuploid series might have originated resulting in $x=8,9$, and 11 (Goldblatt 1981a).

Based on both the Romero Zarco indices and Stebbins' classification, the karyotype should be considered symmetrical, as commonly found in Fabaceae as a whole (Bairiganjan and Patnaik 1989, Kumari and Bir 1990). For instance, st chromosomes are rare in the Fabaceae, and $t$ chromosomes have never been reported (Bairiganjan and Patnaik 1989, Kumari and Bir 1990). Our data agree with the general trends observed in karyotypes of tree taxa from Papilionoideae (Bairiganjan and Patnaik 1989, Kumari and Bir 1990): none of the studied trees exhibited chromosomes with secondary constrictions, and most karyotypes are symmetrical, falling in the "2A" category of Stebbins (1971).

The karyotypes of the eight other species of Sophora analyzed are also mostly composed of several $\mathrm{m}$ pairs with a few sm pairs (Kawakami 1930, Hsu and Huang 1985, Bernal Gonzalez and Martínez Almeraya 1989, Kodama 1989, Kumari and Bir 1990, Palo- 
mino et al. 1993, Tian et al. 1993). Differences were found in the karyotype formula and in the presence of secondary constrictions among these examined species; karyotypic features seem to be taxonomically useful for Sopbora. For instance, Sousa S. and Rudd (1993) recently recognized the genus $S t y p h-$ nolobium Schott as separate from Sopbora based on the existence of postulated basic numbers $(x=14$ for the former and $x=9$ for the latter [Palomino et al. 1993]), as well as some other morphological features (Sousa S. and Rudd 1993).

Sophora fernandeziana is related to $S$. tetraptera J. Mill. from New Zealand and at one time was considered to be conspecific with this geographically distant species (Hemsley 1884, Johow 1896). Both share the same chromosome number (Yeh et al. 1986), but karyotype data are not available for $S$. tetraptera.

Previous studies of the species of the Juan Fernández Archipelago by Sanders et al. (1983), Spooner et al. (1987), and Sun et al. (1990) revealed relatively little chromosomal structural change associated with the endemic flora. In the paper by Sun et al. (1990) there is a report of one possible tetraploid and one possible aneuploid out of 38 species studied chromosomally. The data on Sophora fernandeziana add further strength to the conclusion presented above.

For the Hawaiian flora, Kyhos and Carr (1994) and Carr (1998) pointed out that most of the species are woody perennial forms and are thus in groups that have been evolving for some time. They argue that in such "older" groups there is more genomic/genic stability and thus less tolerance for chromosomal structural changes. The Bonin Island flora is interesting in this context and perhaps constitutes an exception because a substantial number of the species studied cytologically show chromosome differences (Ono 1991). These changes are mostly aneuploidy (about $18 \%$ of the total of 112 species of the endemic flora, and $48 \%$ of the 58 taxa cited in his paper). Ono (1991) noted that a few other species are presumably island polyploid derivatives or island diploid relicts (with polyploid continental presumed derivatives).

Few island endemics have been studied cytologically. From the studies to date, the general pattern, if there is one, seems to be that speciation on islands is largely independent of major chromosomal changes-or at least chromosomal changes that are recognizable as number changes. This does not mean that structural changes (that do not result in changes in number) have not occurred. More data are required on chromosome number, and particularly on karyotypes, before more well-founded generalizations can be made.

\section{Literature Cited}

Bairiganjan, G. C., and S. N. Patnaik. 1989. Chromosomical evolution in Fabaceae. Cytologia 54:51-64.

Bernal Gonzalez, M. C., and M. P. Martínez Almeraya. 1989. Determinación del cariótipo de algunas especies del género Sophora L. sens. lat. (Familia: Leguminosae). M.S. thesis, Universidad Nacional Autónoma de México, México.

Carr, G. D. 1998. Chromosome evolution and speciation in Hawaiian flowering plants. Pages 5-47 in T. F. Stuessy and M. Ono, eds. Evolution and speciation of island plants. Cambridge University Press, Cambridge, United Kingdom.

Federov, A., ed. 1974. Chromosome numbers of flowering plants. Reprint by Otto Koeltz Science Publishers, Koenigstein, Germany.

Goldblatt, P. 1981a. Cytology and the phylogeny of Leguminosae. Pages 427-463 in R. M. Polhill and P. H. Raven, eds. Advances in legume systematics, Part 2. Royal Botanic Gardens, Kew.

. $1981 b$. Chromosome numbers in legumes. II. Ann. Mo. Bot. Gard. 68:551557.

, ed. 1981c. Index to plant chromosome numbers. 1975-1978. Monogr. Syst. Bot. 5:1-259.

1984. Index to plant chromosome numbers. 1979-1981. Monogr. Syst. Bot. 8:1-194.

. 1988. Index to plant chromosome numbers. 1984-1985. Monogr. Syst. Bot. 23:1-122. 
1990. Index to plant chromosome numbers. 1986-1987. Monogr. Syst. Bot. 30:1-243.

. 1991. Index to plant chromosome numbers. 1988-1989. Monogr. Syst. Bot. 40:1-238.

. 1994. Index to plant chromosome numbers. 1990-1991. Monogr. Syst. Bot. $51: 1-267$.

. 1996. Index to plant chromosome numbers. 1992-1993. Monogr. Syst. Bot. 58:1-276.

1998. Index to plant chromosome numbers. 1994-1995. Monogr. Syst. Bot. 69:1-208.

Hemsley, W. B. 1884. Report on the botany of Juan Fernandez, the south-eastern Moluccas, and the Admiralty islands. Report on the scientific results of the voyage of H.M.S. Challenger, Botany. Vol. 1, 1-275. Macmillan, London.

Hsu, P., and S. Huang. 1985. Karyotype of Sophora flavescens Ait. Bull. Bot. Res. NE Forest. Coll. (Harbin) 5:123-126.

Johow, F. 1896. Estudios sobre la flora de la Islas de Juan Fernández. Imprenta Cervantes, Santiago, Chile.

Kawakami, J. 1930. Chromosome numbers in Leguminosae. Bot. Mag. Tokyo 44:319328.

Kodama, A. 1989. Karyotype analyses of chromosomes in eighteen species belonging to nine tribes in Leguminosae. Bull. Hiroshima Agric. Coll. 8:691-706.

Kumari, S., and S. S. Bir. 1990. Karyomorphological evolution in Papilionaceae. J. Cytol. Genet. 25:173-219.

Kyhos, D. W., and G. D. Carr. 1994. Chromosome stability and lability in plants. Evol. Theory 10:227-248.

Levan, A., K. Fredga, and A. Sandberg. 1964. Nomenclature for centromeric position on chromosomes. Hereditas 52:201-220.

Marticorena, C., T. F. Stuessy, and C. M. Baeza. 1998. Catalogue of the vascular flora of the Robinson Crusoe or Juan Fernández Islands, Chile. Gayana Bot. 55:187-211.

Ono, M. 1991. Flora of the Bonin Islands:
Endemism and dispersal mode. Aliso 13:95-105.

Palomino, G., P. Martínez, C. Bernal, and M. Sousa S. 1993. Diferencias cromosómicas entre algunas especies de los géneros Sophora L. y Styphnolobium Schott. Ann. Mo. Bot. Gard. 80:284-290.

Polhill, R. M. 1981. Sophoreae Sprengel (1818). Pages 213-230 in R. M. Polhill and P. H. Raven, eds. Advances in legume systematics, Part 1. Royal Botanic Gardens, Kew.

Romero Zarco, C. 1986. A new method for estimating karyotype asymmetry. Taxon 35:526-530.

Sanders, R. W., T. F. Stuessy, and R. Rodriguez. 1983. Chromosome numbers from the flora of the Juan Fernandez Islands. Am. J. Bot. 70:799-810.

Sousa S., M., and V. Rudd. 1993. Revisión del género Styphnolobium (Leguminosae). Ann. Mo. Bot. Gard. 80:270-283.

Spooner, D. M., T. F. Stuessy, D. J. Crawford, and M. Silva O. 1987. Chromosome numbers from the flora of the Juan Fernandez Islands II. Rhodora 89:351-356.

Stebbins, G. L. 1971. Chromosomal evolution in higher plants. E. Arnold, London.

Stuessy, T. F., K. A. Foland, J. F. Sutter, R. W. Sanders, and M. Silva O. 1984. Botanical and geological significance of potassium-argon dates from the Juan Fernandez Islands. Science (Washington, D.C.) 225: 49-51.

Stuessy, T. F., U. Swenson, D. J. Crawford, G. Anderson, and M. Silva O. 1998. Plant conservation in the Juan Fernandez archipelago, Chile. Aliso 16:89-101.

Sun, B. Y., T. F. Stuessy, and D. J. Crawford. 1990. Chromosome counts from the flora of the Juan Fernández Islands, Chile. III. Pac. Sci. 44:258-264.

Tian, X., B. Zhu, Y. Xiao, Q. Liu, and G. Zhao. 1993. On the karyotypes of five species of Leguminosae. J. Shanxi Univ. Nat. Sci. Ed. 21:62-65.

Yeh, M. S., H. Yuasa, and F. Maekawa. 1986. Chromosome numbers in the Leguminosae. Sci. Rep. Res. Inst. Evol. Biol. 3:57-71. 